and uniformity. These, they say, would be valuable in a situation where state laws against embryo research and cloning are already proliferating into a confusing patchwork.

But federal legislation could present its own risks both to individual reproductive freedom and to scientists. According to R. Alta Charo, a professor of law at the University of Wisconsin, who chaired a policy working group within the commission, a law without a "sunset" provision mandating expiry after a prescribed length of time "is likely to remain in place permanently".

That would constrain individual reproductive freedom if and when cloning technology reached a stage where it was deemed safe and ethical as a human reproductive technology. Some say this will never happen, but other NBAC members are unconvinced that the ethical arguments against cloning humans have been sufficiently developed to justify an indefinite ban.

Others point out that a law could be detrimental to research. Legislation could "easily be drafted inadvertently to cover the kind of simple, molecular DNA cloning that we do every day in laboratories around the country," says Charo.

The use of the new technology to conduct cellular-level research - for instance, on cellular ageing and differentiation - is already effectively barred by an existing congressional ban on human embryo research. Says Cox: "You can't do the cell-based work with any kind of nuclear transplantation without a human oocyte, and having that go through several divisions, which basically makes it an embryo".

NBAC has indicated that it will not challenge the congressional ban, which was attached as a rider to 1996 and 1997 appropriations bills, by, for example, explicitly fencing off human cellular-level research for protection from a broader law or moratorium aimed at cloning for implantation.

That may dismay scientists. Most of the heads of scientific societies who responded to a letter circulated by NBAC are said to support cloning human adult or embryonic nuclei for research in developmental biology and cellular therapeutics.

But even if NBAC were to explicitly recommend protecting cellular research using cloning, some believe Congress would ignore it because many conservatives are so adamantly opposed to embryo research. "Congress has already indicated it will not tolerate [human] embryo research. It's not going to change no matter what NBAC says or does," says Caplan.

That, says George Annas, a professor of public health at Boston University, leaves developmental biologists and others wishing to use the new technology with a considerable challenge. "The trick is to come up with a way to try to do cloning research without human embryos," he says. Meredith Wadman

\title{
France is urged to loosen ban on embryo research
}

[PARIS] France's national bioethics committee last week recommended that the ban on research on human embryos should be loosened to allow the use of embryonic stem cells in fundamental and therapeutic research.

The recommendation, which breaks a taboo on embryo research in France that has its origins in the conservative attitude of the Roman Catholic church, has been prompted by growing awareness that differentiated cell lines derived from these precursor cells could have huge potential therapeutic benefits.

Under legislation passed in 1994, research on human embryos is allowed only if it does not harm the 'integrity' of the embryo - in practice, a complete ban on embryo research.

The committee's recommendation would allow a dispensation only for research on embryonic stem cells. But it nevertheless marks a significant watershed, as it is the first time an unequivocal consensus has been reached in France in favour of allowing any form of human embryo research.

Embryonic stem cells, which occur at the blastocyte stage, can give rise to all tissue types when injected into older embryos, even though the cells themselves are unable to develop into a multicellular embryo or fetus.

In principle, it may be possible to cultivate such cells exvivo, and to manipulate culture conditions to produce large quantities of bone-marrow stem cells for treating leukaemia, for example, or cerebral dopaminergic cells for treating Parkinson's disease. Although this is not yet technically possible in humans, the cloning techniques that produced Dolly the sheep now offer a possible solution (see previous page).

The committee proposes that research on stem cells should be allowed only using surplus conserved embryos, where the parents have confirmed in writing that they no longer wish to use their embryos, and have decided to terminate their conservation. There are more than 300 such embryos in France.

It qualifies its recommendation with a panoply of safeguards, including a ban on the creation of embryos specifically for research, on trade in stem cells and on their use to modify the germ line or create human clones.

Only one member of the committee, Father Olivier de Dinenchin, a Jesuit priest, opposed the decision on embryo research, arguing that there was a choice between allowing surplus embryos to die naturally and using them for research. Taking the latter option, he argued, amounted to "reducing the embryo to an object, a material, for research".

Axel Kahn, director of the INSERM Laboratory of Research on Genetics and Molecular Pathology at the Cochin Institute of Molecular Genetics in Paris, who is also a member of the committee, agrees that there is "incontestably" a danger that the committee's recommendation might be the beginning of a slippery slope towards the utilitarian argument against any limits on what can be done with embryos, particularly early embryos.

But Kahn argues that the new recommendation is a wise compromise between the extreme positions of those who believe embryos should not be experimented on at all and those who believe that early embryos are not persons, and that anything goes.

One interpretation of the committee's recommendation is that it confirms France's reluctance to rule on the question of whether the embryo becomes a person at the moment of conception or at some later point.

In Britain, for example, legislation passed in 1990 allows research on embryos up to fourteen days after fertilization. But there is a broad consensus in French society that the embryo is an 'evolutive entity' and that it is artificial to establish an arbitrary threshold before which everything is permitted and after which all research is banned.

If the committee's recommendations are adopted by the legislature during the scheduled revision of France's bioethics legislation in 1999, it would make French legislation in this area intermediate between that of Germany, where all human embryo research is banned, and that of both the United Kingdom the United States.

The fate of the French ethics committee's recommendation will depend heavily on the outcome of next month's legislative elections. There is widespread hostility to human embryo research, especially among the conservative parties, and on the basis of the parliamentary debates preceding the introduction of bioethics legislation in 1994 , many predict that a new conservative coalition may refuse to implement the panel's recommendations.

Declan Butter

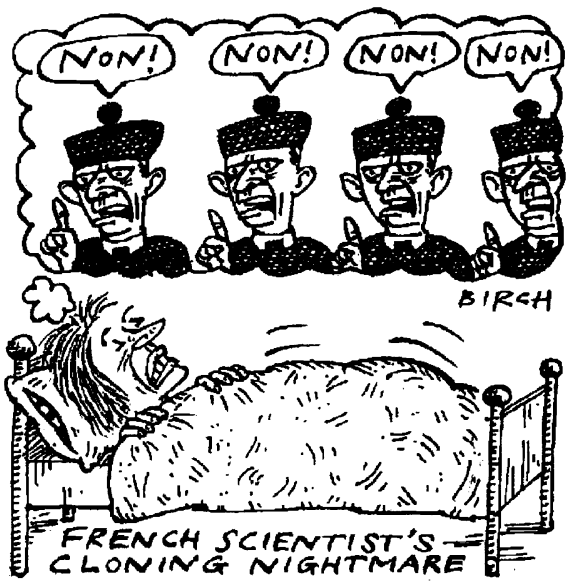

